\title{
Effects of spring soil nitrogen application on nitrogen remobilization, uptake, and partitioning for new growth in almond nursery plants
}

\author{
By G. BI ${ }^{1 *}$, C. F. SCAGEL ${ }^{2}$ and L. H. FUCHIGAMI ${ }^{1}$ \\ ${ }^{1}$ Department of Horticulture, Oregon State University, Corvallis, OR 97331, USA \\ ${ }^{2}$ USDA-ARS, Horticultural Crops Research Laboratory, Corvallis, OR 97330, USA \\ (e-mail: big@science.oregonstate.edu) \\ (Accepted 11 January 2004)
}

\section{SUMMARY}

One year old 'Nonpareil' almond (Prunus dulcis (Mill) D. A. Webb) trees on 'Lovell' rootstocks were used to evaluate the effects of soil nitrogen $(\mathrm{N})$ availability in the spring on $\mathrm{N}$ remobilization, uptake, partitioning, and tree growth. After being transplanted to an $\mathrm{N}$-free medium, the trees received a modified Hoagland solution, with or without $\mathrm{N}$ from ${ }^{15} \mathrm{~N}$-depleted $\mathrm{NH}_{4} \mathrm{NO}_{3}$, twice a week for 12 weeks. During the first four weeks, the $\mathrm{N}$ used for new shoot and leaf growth mainly came from the nitrogen that had accumulated in storage tissues. No significant differences were seen in the amount and duration of $\mathrm{N}$ remobilization between $\mathrm{N}$-fertilized trees and those that received no N. However, trees that were fertilized in the spring had significantly more new shoot and leaf growth. Uptake of ${ }^{15} \mathrm{~N}$ by the roots began two weeks after transplanting. Nitrogen was rapidly taken up from the soil during the period of greatest shoot and leaf growth; leaves were the major sink for $\mathrm{N}$ from both root uptake and storage. Six weeks after transplanting, the whole-tree $\mathrm{N}$ content was significantly higher in fertilized trees than in the controls. We conclude that the remobilization of $\mathrm{N}$ for spring new growth takes place irrespective of the current-year external $\mathrm{N}$ supply. However, the new growth in young almond trees is highly dependent on soil $\mathrm{N}$ availability, which demonstrates the importance of spring $\mathrm{N}$ fertilizer applications following transplantation.

$\mathbf{I}$ $\mathrm{n}$ deciduous fruit trees, the nitrogen $(\mathrm{N})$ used for new growth in the spring may come from two sources: $\mathrm{N}$ stored the previous year and that which is taken up from the soil during the current growing season. The internal remobilization from storage tissues provides the nitrogen needed for early new growth before significant root uptake occurs (Taylor and May, 1967; Titus and Kang, 1982; Millard and Neilsen, 1989). However, as the season progresses, root uptake of nitrogen plays a more important role in satisfying the tree $\mathrm{N}$ demand (Weinbaum et al., 1984a; Sanchez et al., 1990; Rufat and DeJong, 2001). N uptake by roots is also affected by environmental factors such as temperature, soil texture, etc. (Weinbaum et al., 1987; Neilsen et al., 2001a; Dong et al., 2001). For example, in apple trees, a combination of soil temperature and plant developmental stage influences the uptake and use of soil nitrogen in the spring (Dong et al., 2001). The timing of demand for root-supplied $\mathrm{N}$ may depend on whether flowering occurs (Neilsen et al., 2001b). In mature almond trees, the need for nitrogen that is triggered by the presence of fruits may also be involved in regulating its uptake (Weinbaum et al., 1984b).

Spring applications of N can help to satisfy the tree's demand, thereby improving growth and development. Faust (1989) has reported that this practice may enhance flower-bud sizes in apple trees, while Neilsen et al. (2001b) have shown that early applications of $\mathrm{N}$ during the first year of growth increases the amount of flowers, spur leaves, and bourse shoots in the following year. Moreover, when marginally $\mathrm{N}$-deficient peach trees are supplied with $\mathrm{N}$ in early April, without having been treated with $\mathrm{N}$ fertilizer in the fall of the previous year,

*Author for correspondence. they exhibit vegetative growth, fruit size, and yield comparable with those trees that are supplied with soil $\mathrm{N}$ the previous fall (Niederholzer et al., 2001).

Compared with mature trees, nursery trees may be more dependent on the uptake of $\mathrm{N}$ from the soil because of their smaller size, limited storage reservoirs, and vigorous vegetative growth. Exogenous application of nitrogen to young peach trees early in the growing season has been shown to enhance vegetative growth (Taylor and May, 1967); the dry matter of their new shoot and leaves is greater than that measured in non-fertilized trees (Niederholzer et al., 2001). However, for the pear, supplying plants with $\mathrm{N}$ in spring only slightly increases new shoot and leaf growth for the first $70 \mathrm{~d}$ after budbreak (Cheng et al., 2001).

Seasonal N uptake, demand, utilization and cycling in fruit trees have been studied extensively. However, there is at present little research on almond nursery trees. Understanding the effects of the soil-N supply in the spring on $\mathrm{N}$ remobilization, uptake, and vegetative growth in young almond trees is important for optimizing the timing of fertilizer applications to meet tree uptake and demand. Therefore, the objectives of this study on one year old almond trees were to (1) determine whether soil $\mathrm{N}$ application alters $\mathrm{N}$ remobilization; (2) quantify the effects of soil $\mathrm{N}$ availability in the spring on $\mathrm{N}$ uptake, distribution, and new growth; and (3) determine the most efficient time for spring soil $\mathrm{N}$ applications.

\section{MATERIALS AND METHODS \\ Experimental design}

One year old 'Nonpareil' almond (Prunus dulcis (Mill) D. A. Webb) trees on 'Lovell' rootstocks were removed from cold storage and transplanted on 20 April, 2001, 
into 7.61 polyethylene pots containing a 1:2 (v:v) mix of perlite and vermiculite. Before transplanting, five trees had been randomly selected and divided into root and stem portions to measure their $\mathrm{N}$ contents and biomass. The transplanted trees were grown outdoors under natural conditions in Corvallis, Oregon, USA. Uniform trees were selected for our experimental treatments based on height and stem-diameter measurements, and 30 trees were randomly assigned to one of two groups. Beginning the second day after transplanting, the trees were fertigated twice a week for 12 weeks. One group was supplied with $400 \mathrm{ml}$ of an $\mathrm{N}$-free modified Hoagland solution (-N treatment); the other received $400 \mathrm{ml}$ of a modified Hoagland solution containing $10 \mathrm{mM}{ }^{15} \mathrm{~N}$-depleted $\mathrm{NH}_{4} \mathrm{NO}_{3}\left(0.03 \%{ }^{15} \mathrm{~N}\right.$ abundance; ISOTEC, Miamisburg, $\mathrm{OH})(+\mathrm{N}$ treatment). Five trees from each treatment were then randomly selected and harvested every two weeks during the experimental period. Buds started to open $10 \mathrm{~d}$ after transplanting. Some leaves were visible but no measurable new shoot growth was present on either the first or second harvest date. The trees sampled on those two dates were separated into leaf, stem, and root portions. For the remainder of the harvest dates, the samples were divided into leaves, new shoots, stems, and roots. All samples were washed in DD water and dried. The dry weight was recorded for each tissue. The samples were then ground with a 20-mesh Wiley mill and reground with a 60 mesh cyclone mill for determination of total $\mathrm{N}$ and ${ }^{15} \mathrm{~N}$.

\section{Analysis of samples}

Total-N concentrations were determined with an autoanalyzer after micro-Kjeldahl digestion (Schuman et al., 1973). The atom $\%{ }^{15} \mathrm{~N}$ in the samples was determined by mass spectrometry, and the percentage of nitrogen derived from the labelled fertilizer (NDFF\%) was calculated as:

$$
N D F F \%=\frac{\left(\text { atom } \%{ }^{15} N\right)_{\text {natural.abundance }}-\left(\text { atom } \%{ }^{15} N\right)_{\text {tissue }}}{\left(\text { atom } \%{ }^{15} N\right)_{\text {natural.abundance }}-\left(\text { atom } \%{ }^{15} N\right)_{\text {fertilizer }}} \times 100 \%
$$

The ${ }^{15} \mathrm{~N}$ content in each tissue was calculated from NDFF $\%$ and tissue total-N content. The total amount of ${ }^{15} \mathrm{~N}$ taken up per tree was calculated by pooling the ${ }^{15} \mathrm{~N}$ content in each tissue. The total $\mathrm{N}$ content in the new shoots and leaves from non- $\mathrm{N}$ fertigated trees was regarded as the amount of $\mathrm{N}$ remobilized from their storage tissues. The difference between total- and labelled- ${ }^{15} \mathrm{~N}$ content of the new shoots and leaves from $\mathrm{N}$-fertigated trees was used to estimate the amount of nitrogen they had remobilized.

\section{Statistical analysis}

The experimental design was completely randomized, with five replicates per treatment per harvest date. Data for dry weights and $\mathrm{N}$ contents were analysed using a two-factor ANOVA model, with the main effects being time after planting and $\mathrm{N}$ treatment $(+\mathrm{N}$ and $-\mathrm{N})$. Comparisons of the means at different harvest dates with the means measured at the beginning of the experiment were performed using $t$-tests, adjusting for multiple comparisons via Dunnett's method. Comparisons of means at individual dates between fertilized and nonfertilized plants were performed with $t$-tests, adjusting for multiple comparisons using Tukey's method. All statistical analyses were conducted with SAS (SAS Institute Inc., Cary, N.C.).

\section{RESULTS AND DISCUSSION \\ Plant growth}

The seasonal patterns of growth were similar in $\mathrm{N}$ fertilized $(+\mathrm{N})$ and non-fertilized $(-\mathrm{N})$ trees (Figure 1). Total-tree dry weights increased slowly during the first four weeks after transplanting (Figure 1A). Significant increases $(P<0.0001)$ in total-tree dry weights were not detectable until six weeks after transplanting for both fertilized and non-fertilized trees. Thereafter, increases were rapid until the end of the experiment. Significant differences $(P<0.0001)$ in total-tree dry weights between fertilized and non-fertilized trees were detectable eight weeks after transplanting. The rate of dry-weight accumulation varied between $+\mathrm{N}$ and $-\mathrm{N}$ trees over time (Figure 1B), with amounts accumulated in the first 12 weeks being $48 \%$ greater in the former $(1.15 \mathrm{mg} \mathrm{v} 0.77$ $\mathrm{mg}$ tree ${ }^{-1}$ day $\left.^{-1}\right)$. This suggests that, starting four weeks after transplanting, the fertilized trees not only accumulated more dry weight, but also at a faster rate.

Dry weights of leaves (Figure 2A), new shoots (Figure 2B), roots (Figure 2C), and stems (Figure 2D) also varied with time for the fertilized and non-fertilized trees. New leaves grew more rapidly during 6-10 weeks post-transplanting in the $+\mathrm{N}$ compared with $-\mathrm{N}$ trees. While the new shoot growth was more rapid in the $+\mathrm{N}$ than $-\mathrm{N}$ trees between $8-10$ weeks post-transplanting.
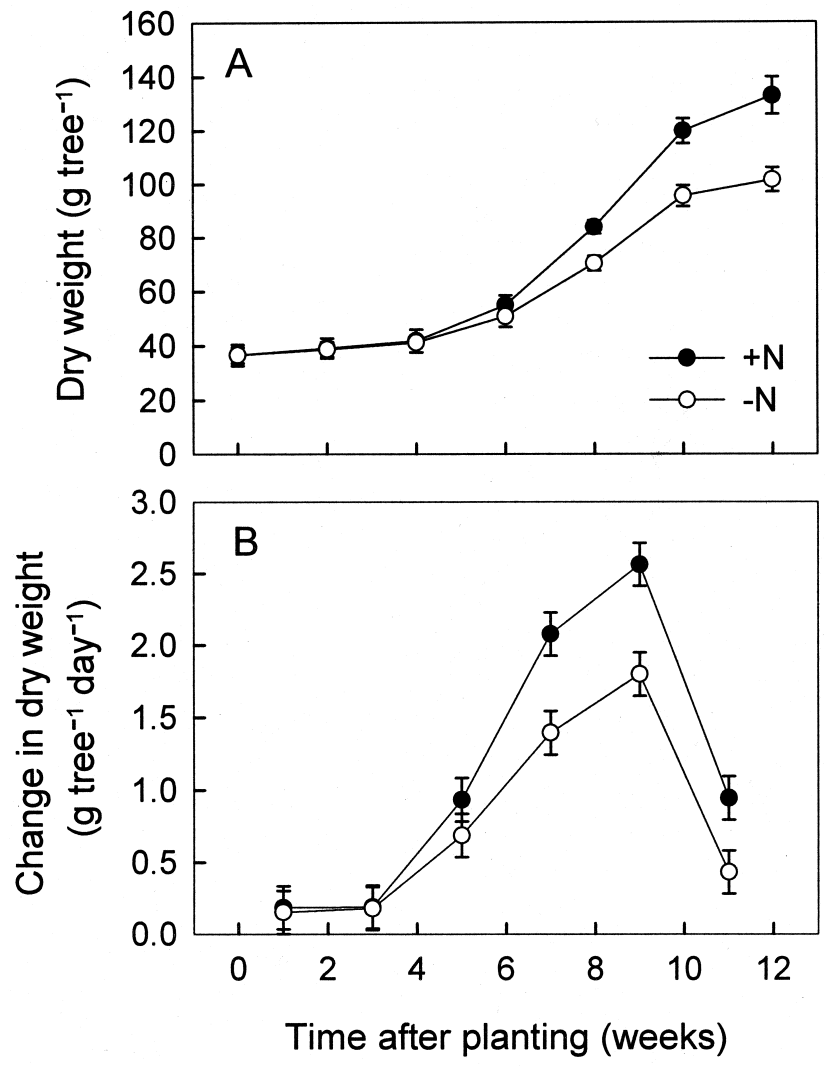

FIG. 1

Total tree dry weight (A) and change in total tree dry weight (B) of young almond trees fertigated with nitrogen $(\mathrm{N})(+\mathrm{N})$ or without $\mathrm{N}$ $(-\mathrm{N})$ in the spring. Each data point represents the least squares mean; error bars are SEs of the mean of five replicates. 
TABLE I

Percentage of nitrogen derived from ${ }^{15} \mathrm{~N}$ fertilizer (NDFF\%) in leaf, stem, root and new shoot tissues following spring applications of ${ }^{15} \mathrm{~N}$ fertilizer to soil of young almond trees

\begin{tabular}{ccrc}
\hline & & \multicolumn{2}{c}{ NDFF (\%) in tissues } \\
\cline { 2 - 4 } Weeks after planting & \multicolumn{1}{c}{ Leaves } & \multicolumn{1}{c}{ Stems } & \multicolumn{1}{c}{ Roots } \\
\hline 2 & $0.37 \pm 0.19^{y}$ & $0.51 \pm 0.19$ & $1.01 \pm 0.19$ \\
4 & $15.95 \pm 3.09$ & $6.86 \pm 1.82$ & $3.44 \pm 2.95$ \\
6 & $39.57 \pm 3.29$ & $18.61 \pm 1.28$ & $33.56 \pm 1.31$ \\
8 & $57.36 \pm 1.92$ & $34.03 \pm 1.52$ & $58.00 \pm 3.90$ \\
10 & $65.73 \pm 3.13$ & $49.96 \pm 3.37$ & $70.37 \pm 4.68$ \\
12 & $69.04 \pm 5.32$ & $55.43 \pm 4.02$ & $75.85 \pm 4.35$ \\
\hline
\end{tabular}

${ }^{\mathrm{z}}$ Shoot tissue from 2001 growing season.

${ }^{\mathrm{y}}$ Mean \pm the SE of 5 replicates.

Supplying plants with $\mathrm{N}$ in the spring increased the growth of new shoots, leaves, and stems, as seen in the $34 \%$ greater dry weights measured from fertilized trees by the end of the experimental period. This demonstrated relationship between growth and currentyear $\mathrm{N}$ supply is consistent with results reported for peaches and other tree fruit species (Oland, 1959; Niederholzer et al., 2001; Rufat and DeJong, 2001).

Compared with the performance of above-ground tissues, root growth showed differential responses to $\mathrm{N}$ fertilization (Figure 2C), with dry weights from fertilized trees being slightly, but non-significantly $(P>0.05)$, lower than those of the roots from the controls. Trees that were treated with $\mathrm{N}$ had comparable root systems, but supported a larger above-ground biomass than did trees grown without N. Similar results have been reported with apple (Millard and Neilsen, 1989) and pear (Cheng et al., 1998). This partitioning of dry matter may be a mechanism used by plants to optimize the available resources. When ample soil $\mathrm{N}$ is available and other factors do not restrict its uptake, a relatively small root system is sufficient. However, when nitrogen levels are low, trees tend to allocate more biomass to the root systems to maximize the uptake of available nutrients.

Uptake and translocation of ${ }^{15} \mathrm{~N}$

The appearance of ${ }^{15} \mathrm{~N}$ in tree tissues was used to determine when nitrogen uptake from fertilizer started. ${ }^{15} \mathrm{~N}$ was detected in the roots two weeks after

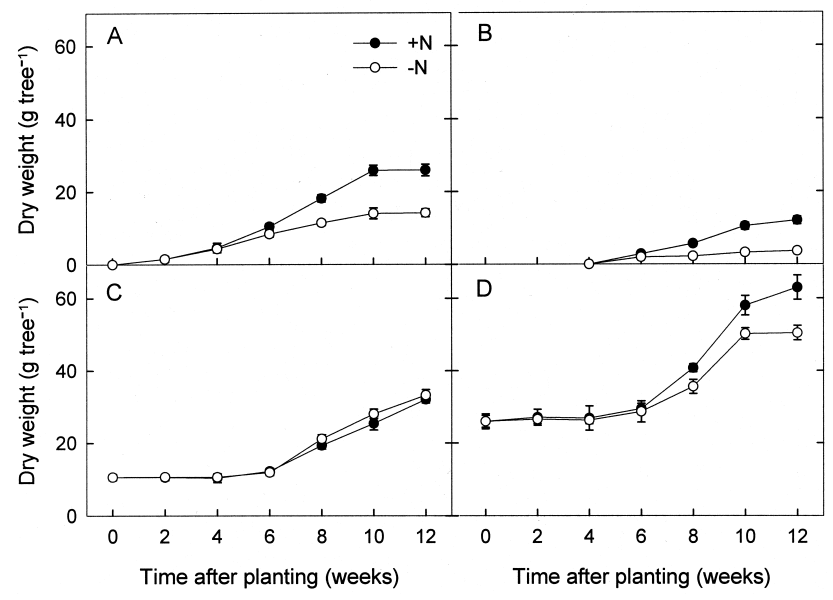

FIG. 2

Dry weight of leaves (A), new shoots (B), roots (C), and stems (D) of young almond trees fertigated with nitrogen $(\mathrm{N})(+\mathrm{N})$ or without $\mathrm{N}$ $(-\mathrm{N})$ in the spring. Each data point represents the least squares mean; error bars are SEs of the mean of five replicates. transplanting (Table I). Significant amount of ${ }^{15} \mathrm{~N}$ was measured in plant tissues four weeks after transplanting, indicating that significant uptake of $\mathrm{N}$ from the soil began 2-4 weeks after nitrogen was applied. This timing in young almond trees is slightly earlier than that reported for young apple, in which roots begin their uptake approximately three weeks after budbreak (Cheng and Fuchigami, 1997). The presence of ${ }^{15} \mathrm{~N}$ in the stems and leaves at two weeks post-transplanting (Table I) indicates that translocation was rapid to the above-ground portions. Similar results have been found in mature almond trees, where isotopic $\mathrm{N}$ is detected in both developing fruit and leaves within two weeks following ${ }^{15} \mathrm{~N}$-fertilizer application to the soil in March (Weinbaum et al., 1984a).

During the first four weeks after transplanting, prior to rapid shoot expansion, the rate of ${ }^{15} \mathrm{~N}$ uptake was low. This may have been due to a combination of factors: (1) Low demand for nitrogen because of slower new growth (Figure 1 and Figure 2); (2) N remobilization from storage tissues, which plays a key role in supporting the growth of deciduous tree fruits in spring (Titus and Kang, 1982; Tromp, 1983; Millard, 1995); (3) root damage due to transplanting (Dong et al., 2003); and (4) environmental factors, such as low soil temperature in early spring decreased rates of $\mathrm{N}$ uptake by the roots (Hogue and Neilson, 1986; McMichael and Burke, 1998; Dong et al., 2001).

${ }^{15} \mathrm{~N}$ was taken up quickly between four and ten weeks after transplanting, coinciding with a period of rapid growth by the leaves and new shoots. This suggests that the uptake of nitrogen is correlated with the rate of spring new growth. Reports on apple, peach, and mature almonds have also shown that uptake can be affected by high demands for $\mathrm{N}$ during the period of vigorous spring vegetative growth (Weinbaum et al., 1984b, 1987; Munoz et al., 1993; Neilsen et al., 2001b).

\section{Distribution of ${ }^{15} \mathrm{~N}$}

At two weeks after transplanting, when uptake of ${ }^{15} \mathrm{~N}$ was very low, $64 \%$ of the ${ }^{15} \mathrm{~N}$ taken up by the roots was present in the root tissues; $35 \%$ in the stems (Figure 3). By six weeks post-transplanting, however, the new shoots had started to rapidly expand, and $57 \%$ of the $\mathrm{N}$ that had been taken up by the roots was now detected in the leaves, $13 \%$ in stems, $22 \%$ in roots, and $8 \%$ in shoots (Figure 3 ). Leaves, as a major sink, accumulated the highest amount of translocated ${ }^{15} \mathrm{~N}$, an observation also reported with other tree fruit species, e.g., pecan (Kraimer et al., 2001), apple (Neilsen et al., 2001a, 2001b), and peach 


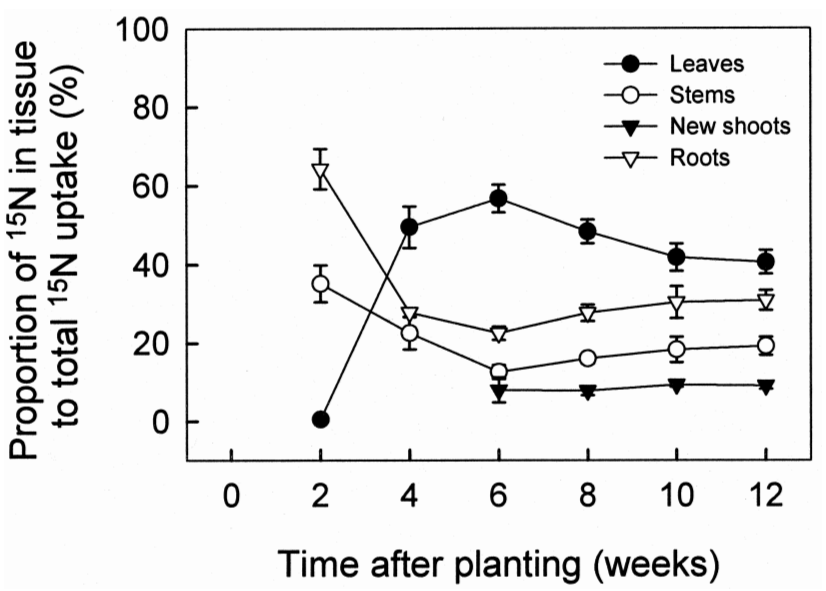

FIG. 3

Distribution of ${ }^{15} \mathrm{~N}$ in leaves, stems, new shoots and roots following ${ }^{15} \mathrm{~N}$ fertigation of young almond trees in the spring. Each data point represents the least squares mean; error bars are SEs of the mean of five replicates.

(Niederholzer et al., 2001). However, for mature fruit trees, the fruit may become a more important sink for $\mathrm{N}$ partitioning later in the growing season (Neilsen et al., 2001a; Niederholzer et al., 2001).

\section{Tree $N$ content}

Six weeks after transplanting, the total $\mathrm{N}$ content from fertilized trees was significantly higher $(P<0.0001)$ than from those that received no N (Figure 4), and continued to increase rapidly between six and 12 weeks after planting. By the end of the experiment, the total amount of nitrogen was about three times higher in the fertilized trees. Fertilization with $\mathrm{N}$ in the spring significantly increased almond nursery tree $\mathrm{N}$ content similar to results reported for mature peach trees, applying $\mathrm{N}$ in the spring (200 kg N ha ${ }^{-1}$ in April) results in a total tree $\mathrm{N}$ content that is nearly double that measured in non-fertilized trees (Rufat and DeJong, 2001).

Leaf-N content began increasing in both treated and control trees between two and four weeks after transplanting (Figure 5A). Although the fertilized trees started accumulating $\mathrm{N}$ from both reserves and soil for new leaf growth during that early period (Figure 5A), new shoots did not start their accumulation until 4-6 weeks after transplanting (Figure 5B). In contrast, the leaves and new shoots of non-fertilized trees had to depend entirely on $\mathrm{N}$ reserves. Six weeks posttransplanting, when rapid shoot elongation occurred, the amount of $\mathrm{N}$ used for shoots was higher in the fertilized trees (Figure 5B). In the control plants, a higher proportion of reserve $\mathrm{N}$ was used to promote new leaf growth, coming at the expense of shoot development.

In the first 2-6 weeks, $\mathrm{N}$ content in the roots (Figure 5C) and stems (Figure 5D) decreased, prior to rapid shoot elongation. Remobilized nitrogen from storage in the roots and stems was used primarily in the new leaves. Six to 12 weeks after transplanting, the $\mathrm{N}$ content in the roots and stems of fertilized trees increased in conjunction with an increased uptake rate from the soil. In contrast, the $\mathrm{N}$ content for stems of our control trees remained relatively constant during the time when no $\mathrm{N}$ was being supplied externally and little was being remobilized for new growth. However, in the same

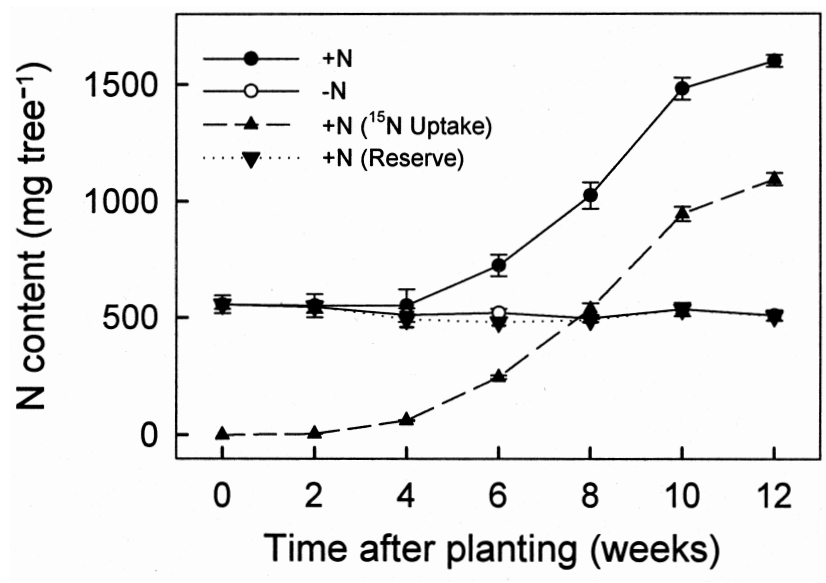

FIG. 4

Total-tree $\mathrm{N}$ content of young almond trees fertigated with nitrogen $(\mathrm{N})$ $(+\mathrm{N})$ or without $\mathrm{N}(-\mathrm{N})$ in the spring. Each data point represents the least squares mean; error bars are SEs of the mean of five replicates. $+\mathrm{N}$ $\left({ }^{15} \mathrm{~N}\right.$ uptake $)=$ total $-{ }^{15} \mathrm{~N}$ content in trees that were fertigated with $\mathrm{N} .+\mathrm{N}$ (Reserve) $=$ difference between the total-N and labelled $-{ }^{15} \mathrm{~N}$ contents in trees that were fertigated with $\mathrm{N}$ (= reserve $\mathrm{N}$ remobilized in $\mathrm{N}$-fertigated plants).

period, the $\mathrm{N}$ content in roots of trees receiving no fertilizer was slightly higher. For them, some of the nitrogen that had been remobilized from the roots to support new above-ground growth may have been mobilized back to the roots to stimulate their development. Similar observations have been made with one year old apple (Millard and Neilsen, 1989), in which $\mathrm{N}$-deficient plants withdraw nitrogen from their leaves to reinvest to the roots after the initial phase of leaf growth. This appears to be a plant response mechanism in $\mathrm{N}$ deficient environments.

\section{$N$ remobilization}

During the first four weeks after transplanting, the nitrogen used for new growth by our almond trees came mainly from the $\mathrm{N}$ stored in the roots and stems (Figure 5). As uptake increased, the release of stored $\mathrm{N}$

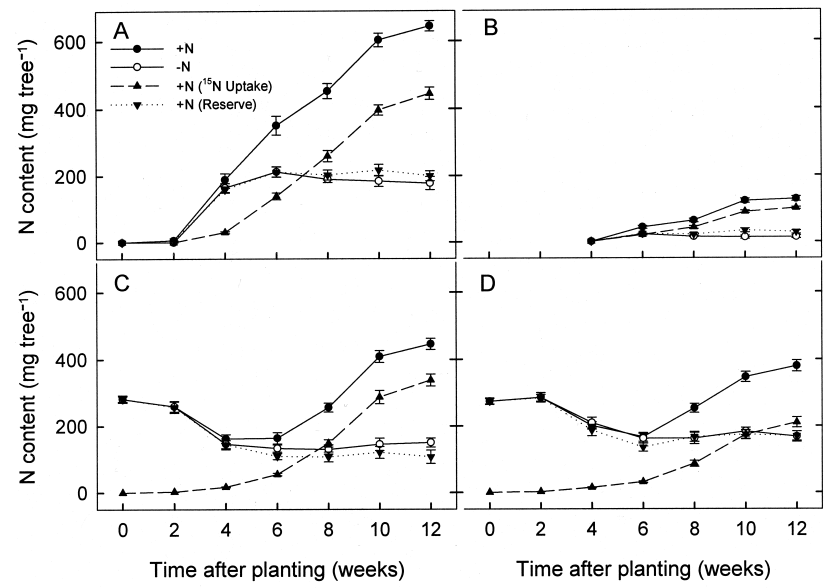

FIG. 5

$\mathrm{N}$ content of leaves (A), new shoots (B), roots (C), and stems (D) of young almond trees fertigated with nitrogen $(\mathrm{N})(+\mathrm{N})$ or without $\mathrm{N}$ $(-\mathrm{N})$ in the spring. Each data point represents the least squares mean; error bars are SEs of the mean of five replicates. $+\mathrm{N}\left({ }^{15} \mathrm{~N}\right.$ uptake $)=$ total $-{ }^{15} \mathrm{~N}$ content in trees that were fertigated with $\mathrm{N} .+\mathrm{N}($ Reserve $)=$ difference between the total-N and labelled- ${ }^{15} \mathrm{~N}$ contents in trees that were fertigated with $\mathrm{N}$ (=reserve $\mathrm{N}$ remobilized in $\mathrm{N}$-fertigated plants). 
decreased and ended approximately six weeks after transplanting. By this point, rapid shoot elongation had commenced. In all, about half the total tree $\mathrm{N}$ detected at transplanting time was remobilized for new growth (primarily leaves). The total amount and the duration of $\mathrm{N}$ remobilization did not differ significantly between the $+\mathrm{N}$ and $-\mathrm{N}$ fertigated trees (Figure 4). Stored $\mathrm{N}$ was utilized for new growth irrespective of the externally available nitrogen. Moreover, the amount that was remobilized depended mainly on the amount that had been stored, and was unaffected by the current $\mathrm{N}$ supply. This result is similar to the pattern of spring $\mathrm{N}$ remobilization reported for other tree fruit species (Millard and Neilsen, 1989; Millard, 1996; Neilsen et al., 1997).

Numerous studies have described the remobilization of nitrogen in deciduous tree fruits. Newly planted apple trees mainly use stored $\mathrm{N}$ for new growth for 35 to $55 \mathrm{~d}$ after planting (Neilsen et al., 2001b). Approximately $50-55 \%$ of the nitrogen in dormant young apple trees is used to support new growth (Neilsen et al., 2001b; Cheng and Fuchigami, 2002). The remobilization of $\mathrm{N}$ in young, fruiting apple trees ends by $5 \mathrm{~d}$ after full bloom (Neilsen et al., 1997). In peach trees, all $\mathrm{N}$ used for new growth during the first 25 to $30 \mathrm{~d}$ of the growing season came from storage; remobilization continues until about $75 \mathrm{~d}$ post-anthesis (Rufat and DeJong, 2001). With young almond trees, we found that the amount of stored $\mathrm{N}$ was limited due to the small tree size, and was insufficient to achieve maximum new growth. Therefore, the supply of readily accessible stored $\mathrm{N}$ was exhausted by the end of six weeks after transplanting, when the rate of new shoot elongation was greatest. Although that earliest growth was related to the level of nitrogen reserves, development after those first six weeks was highly dependent on external N. When an exogenous nitrogen source was not available after the stored-N supply was nearly exhausted, new growth was affected. This was manifested by typical N-deficiency symptoms, which were observed later in the growing season.

Compared with other tree fruit species, almond is a heavy consumer of nitrogen (Weinbaum et al., 1987), with an estimated $50 \%$ of the tree $\mathrm{N}$ being replaced annually from the soil in mature almond trees (Weinbaum et al., 1987). Despite the presence of an endogenous pool of previously assimilated $\mathrm{N}$, mature almond trees appear to be highly dependent on the annual availability of soil $\mathrm{N}$ (Weinbaum et al., 1984a). Our data for young almond trees support this observation, and can be used to emphasize the importance of having nitrogen available to promote plant new growth in this species.

In conclusion, spring soil application of nitrogen fertilizer significantly enhances new shoot and leaf growth in young almond trees. Uptake of $\mathrm{N}$ from the soil begins two weeks after its application, and is correlated with the rate of new growth. Maximum uptake occurs during the period of rapid new growth. Leaves are the major sink for nitrogen from both stored $\mathrm{N}$ and that taken up by the roots, and shoot growth is severely inhibited when nitrogen fertilizer is not provided. Trees fertilized in the spring have $\mathrm{N}$ contents that are approximately three times greater than that measured in untreated trees. Therefore, our results suggest that applying $\mathrm{N}$ fertilizer in the spring, during the period of rapid new growth, can significantly improve vegetative growth and the $\mathrm{N}$ status of young almond trees.

This work was supported, in part, by the California Fruit Tree, Nut Tree, and Grapevine Improvement Advisory Board, and by USDA-ARS.

\section{REFERENCES}

ChENG, L. and Fuchigami, L. H. (1997). Regrowth performance of apple nursery plants in relation to reserve and current uptake nitrogen. Annual Progress Report for Washington Tree Fruit Research Commission, 14-21.

Cheng, L. and Fuchigami, L. H. (2002). Growth of young apple trees in relation to reserve nitrogen and carbohydrates. Tree Physiology, 22, 1297-303.

Cheng, L., Dong, S., GuaK, S. and Fuchigami, L. H. (1998). Effects of nitrogen fertigation on dry matter accumulation, partitioning of nitrogen and carbon, and regrowth performance of pear nursery plants. Progress report to Washington Tree Fruit Research Commission for 1998.

Cheng, L., Dong, S., GuaK, S. and Fuchigami, L. H. (2001). Effects of nitrogen fertigation on reserve nitrogen and carbohydrate status and regrowth performance of pear nursery plants. Acta Horticulturae, 564, 51-62.

Dong, S., Scagel, C. F., Cheng, L., Fuchigami, L. H. and RygieWICZ, P. T. (2001). Soil temperature and plant growth stage influence nitrogen uptake and amino acid concentration of apple during early spring growth. Tree Physiology, 21, 541-7.

Dong, S., Cheng, L., Scagel, C. F. and Fuchigami, L. H. (2003). Root damage affects nitrogen uptake and growth of young Fuji/M.26 apple trees. Journal of Horticultural Science \& Biotechnology, 78, 410-5.

FAust, M. (1989). Physiology of temperate zone fruit trees. Wiley Interscience, New York, USA.

Hogue, E. J. and Neilsen, G. H. (1986). Effect of root temperature and varying cation ratios on growth and leaf cation concentration of apple seedlings grown in nutrient solution. Canadian Journal of Plant Science, 66, 637-45.
Kraimer, R. A., Lindemann, W. C. and Herrera, E. A. (2001). Distribution of ${ }^{15} \mathrm{~N}$-labeled fertilizer applied to pecan: A case study. HortScience, 36, 308-12.

McMichael, B. L. and Burke, J. J. (1998). Soil temperature and root growth. HortScience, 33, 947-51.

MillaRd, P. (1995). Internal cycling of nitrogen in trees. Acta Horticulturae, 383, 3-13.

Millard, P. (1996). Ecophysiology of the internal cycling of nitrogen for tree growth. Journal of Plant Nutrition and Soil Science, 159, $1-10$.

Millard, P. and Neilsen, G. H. (1989). The influence of nitrogen supply on the uptake and remobilization of stored $\mathrm{N}$ for the seasonal growth of apple trees. Annals of Botany, 63, 301-9.

Munoz, N., Guerri, J., Legaz, F. and Primo-Millo, E. (1993). Seasonal uptake of ${ }^{15} \mathrm{~N}$-nitrate and distribution of absorbed nitrogen in peach trees. Plant and Soil, 150, 263-9.

Neilsen, D., Millard, P., Neilsen, G. H. and Hogue, E. J. (1997). Sources of $\mathrm{N}$ for leaf growth in a high density apple (Malus domestica) orchard irrigated with an ammonium nitrate solution. Tree Physiology, 17, 733-9.

Neilsen, D., Millard, P., Herbert, L. C., Neilsen, G. H., Hogue, E. J., PARchomchuK, P. and Zebarth, B. J. (2001a). Nitrogen uptake, efficiency of use, and partitioning for growth in young apple trees. Journal of the American Society for Horticultural Science, 126, 144-50.

Neilsen, D., Millard, P., Herbert, L. C., Neilsen, G. H., Hogue, E. J., Parchomchuk, P. and Zebarth, B. J. (2001b). Remobilization and uptake of $\mathrm{N}$ by newly planted apple (Malus domestica) trees in response to irrigation method and timing of $\mathrm{N}$ application. Tree Physiology, 21, 513-21. 
Niederholzer, F. J. A., Dejong, T. M., Saenz, J. L., Muraoka, T. T. and Weinbaum, S. A. (2001). Effectiveness of fall versus spring soil fertilization of field-grown peach trees. Journal of the American Society for Horticultural Science, 125, 644-8.

Oland, K. (1959). Nitrogenous reserves of apple trees. Physiologia Plantarum, 12, 594-648.

RufAT, J. and DEJong, T. M. (2001). Estimating seasonal nitrogen dynamics in peach trees in response to nitrogen availability. Tree Physiology, 21, 1133-40.

Sanchez, E. E., Righetti, T. L., Sugar, D. and Lombard, P. B. (1990). Seasonal differences and soil texture alter uptake of newly absorbed nitrogen in field-grown pear trees. Journal of Horticultural Science, 65, 395-400.

Schuman, G. E., Stanley, M. A. and Knudsen, D. (1973). Automated total nitrogen analysis of soil and plant samples. Proceedings of the Soil Science Society of America, 37, 480-1.

TAYLOR, B. K. and MAY, L. H. (1967). The nitrogen nutrition of the peach tree. II. Storage and mobilization of nitrogen in young trees. Australian Journal of Biological Science, 20, 389-411.
TiTus, J. S. and KANG, S. M. (1982). Nitrogen metabolism, translocation, and recycling in apple trees. Horticultural Reviews, 4, 204-46.

Tromp, J. (1983). Nutrient reserves of roots of fruit trees, in particular carbohydrates and nitrogen. Plant and Soil, 71, 401-3.

Weinbaum, S. A., Klein, I., Broadbent, F. E., Micke, W. C. and MuraOKA, T. T. (1984a). Use of isotope nitrogen to demonstrate dependence of mature almond trees on annual uptake of soil nitrogen. Journal of Plant Nutrition, 7, 975-90.

Weinbaum, S. A., Klein, I., Broadbent, F. E., Micke, W. C. and MuraOKA, T. T. (1984b). Effects of time of nitrogen application and soil texture on the availability of isotopically labeled fertilizer nitrogen to reproductive and vegetative tissue of mature almond trees. Journal of the American Society for Horticultural Science, 109, 339-43.

Weinbaum, S. A., Klein, I and Muraoka, T. T. (1987). Use of nitrogen isotopes and a light-textured soil to assess annual contributions of nitrogen from soil and storage pools in mature almond trees. Journal of the American Society for Horticultural Science, 112, 526-9. 